\title{
KARAKTERISASI DAN IDENTIFIKASI KOMPONEN KIMIA RIMPANG KUNYIT (Curcuma domestica Val.) SEBAGAI INHIBITOR BAKTERI PATOGEN
}

\author{
Herson Cahaya Himawan ${ }^{1}$, VinsensiusSurjana ${ }^{2}$, Laura Prawira ${ }^{3}$ \\ ${ }^{1,3}$ Sekolah Tinggi Teknologi Industri dan Farmasi Bogor \\ ${ }^{2}$ Laboratorium Pengawasan Mutu, PT Givaudan Indonesia Jl. Raya Jakarta Bogor
}

Km 35, Cimanggis 16951

\begin{abstract}
ABSTRAK
Kunyit (Curcuma domestica Val.) merupakan tanaman tradisional Indonesia yang banyak dimanfaatkan dalam berbagai bidang. Ekstrak kunyit diketahui memiliki aktivitas antibakteri dimana khasiat obat pada kunyit berasal dari senyawa kurkuminoid yang mayoritas terdiri atas kurkumin. Penelitian ini dilakukan untuk menentukan komponen kimia rimpang kunyit yang berperan sebagai inhibitor bakteri patogen. Pembuatan ekstrak rimpang kunyit menggunakan metode maserasi dengan pelarut n-heksana, etilasetat, dan etanol 96\%. Uji aktivitas antibakteri ekstrak kunyit terhadap beberapa bakteri patogen dilakukan dengan metode kertas cakram. Standar kurkumin digunakan sebagai pembanding. Purifikasi dengan Kromatografi Lapis Tipis (KLT) dan profil Kromatografi Cair Kinerja Tinggi (KCKT) digunakan sebagai uji identifikasi untuk mengetahui komponen kimia rimpang kunyit yang berperan sebagai inhibitor bakteri patogen. Hasil penelitian menunjukkan ekstrak etanol rimpang kunyit memiliki aktivitas antibakteri terhadap bakteri Bacillus subtilis, Pseudomonas aeruginosa, Escherichia coli, dan Salmonella typhosa. Fraksi 2 dan fraksi 3 ekstrak etanol memiliki aktivitas antibakteri tertinggi pada bakteri Escherichia coli dan Salmonella typhosa. Purifikasi dengan Kromatografi Lapis Tipis menunjukkan 3 senyawa yang memiliki aktivitas antibakteri dengan aktivitas tertinggi pada preparatif 1 dan preparatif 2 dengan daya hambat pada lama inkubasi 24 jam sebesar $7 \mathrm{~mm}$ dan $8 \mathrm{~mm}$ untuk bakteri Escherichia coli dan sebesar $8 \mathrm{~mm}$ untuk bakteri Salmonella typhi. Hasil Kromatografi Cair Kinerja Tinggi senyawa 1 dan 2 menunjukkan puncak pada waktu retensi 3,621 dan 3,567 menit dibandingkan dengan standar kurkumin yaitu 3,570 menit.
\end{abstract}

Kata kunci: Rimpang kunyit, maseri, bakteri patosigen, Kromatografi Lapis Tipis, Kromatografi Cair Kinerja Tinggi.

\section{PENDAHULUAN}

Indonesia terletak di daerah khatulistiwa dengan iklim tropis yang memungkinkan matahari bersinar sepanjang tahun. Keuntungan letak geografis tersebut menjadikan Indonesia sebagai sumber berbagai jenis kekayaan hayati. MasyarakatIndonesia telah mengenal beragam obat tradisional yang berasal dari kekayaan hayati terutama tumbuhan. Sampai saat ini diketahui bahwa seperempat obat yang adadi dunia diperoleh dari tumbuhan yang salahsatu diantaranya adalah kunyit (Rukmana, R., 1994).
Kunyit (Curcuma domesti banyak 4) ca Val.) merupakan tanaman rempah yang sangat populer di Indonesia. Tanaman ini telah dimanfaatkan secara luas. Selain digunakan sebagai bumbu penyedap makanan, manfaat lain dari kunyit adalah sebagai obat herbal yang berguna untuk menjaga kesehatan dan merawat kecantikan. Kunyit juga telah banyak dimanfaatkan dalam berbagai bidang, diantaranya sebagai anti inflamatori, anti oksidan, anti alergi, anti kanker, anti mikroba, dan antifungi (Jain et al., 2007). 
Khasiat obat pada kunyit berasal dari senyawa kurkuminoid yang mayoritas terdiri atas kurkumin. Senyawa kurkuminoid tersebut juga dapat dimanfaatkan sebagai pewarna makanan alami yang aman dikonsumsi. Berdasarkan penelitian secara ilmiah telah banyak dilaporkan aktivitas kurkumin, antara lain sebagai antioksidan, antiinflamasi, antibakteri dan antikanke (Guenther, 1987).

Hastuti telah melakukan penelitian (1997) tentang uji aktivitas infus rimpang kunyit sebagai antidiare dengan menggunakan metode "Castor oil-induced diarrhea", atau minyak jarak sebagai penyebab diare pada tikus putih dengan hasil bahwa infus rimpang kunyit dengan konsentrasi $15 \%$ mempunyai khasiat sebagai antidiare (Tjay dan Rahardja, 2002).

Pada penelitian sebelumnya Singh dan Rai , (2000) juga melaporkan bahwa minyak esensial kunyit mempunyai aktivitas antimikroba terhadap isolat $S$. Aureus klinik dan standar. Hasilnya didapatkan pada isolat standar, minyak esensial kunyit mempunyai aktivitas hambat lebih rendah dari pada isolat klinik.

\section{BAHAN DAN METODE}

\section{Bahan dan Alat}

Bahan yang digunakan dalam penelitian ini meliputi rimpang kunyit tua yang dipanen pada usia 8-18 bulan, semua bahan yang digunakan berkualitas pro analisis kecuali disebutkan lain yaitu; aquadest, etanol 96\%, n-heksan, etil asetat, $\mathrm{NaCl}$ 0,9\%, media Nutrient Agar (Merck), media Lactose Broth (Merck), Escherichia coli NBRC 14237, Pseudomonas aeruginosa ATCC 9027, Salmonella typhi
P2KIMC, Bacillus subtilis BTCC B612, suspensi standar McFarland.

Alat penelitian yang digunakan antara lain : paper disc, rotary evaporator, kromatografi lapis tipis, KCKT Shimadzu CLASS-VP, silika gel F254, vortex.

\section{Metode}

Identifikasi Tumbuhan

Identifikasi tumbuhan dilakukan di Herbarium Bogoriense Bidang Botani Pusat Penelitian Biologi LIPI, Cibinong Bogor.

\section{Ekstraksi Senyawa Rimpang Kunyit}

Sampel rimpang kunyit (Curcuma domestica Val.) yang diperoleh dari Pasar Induk Jambu Dua Bogor dibersihkan dari pengotor yang melekat dan dicuci dengan air PAM mengalir hingga bersih, lalu ditiriskan dan dipotong kecil-kecil kemudian dikeringkan pada temperatur $55^{\circ} \mathrm{C}$ selama 4 hari. Hasil pengeringan kemudian digiling sampai halus hingga berbentuk serbuk. Duaratus gram serbuk halus rimpang kunyit ditimbang kemudian dimaserasi dengan $400 \mathrm{ml}$ pelarut dan diekstrak selama 24 jam. Ekstrak kemudain diuapkan dengan Rotary Evaporator sehingga diperoleh ekstrak kental

\section{Isolasi Bakteri Patogen dan Uji Antibakteri \\ Penyiapan Inokulum Bakteri Patogen}


Bakteri diinokulasikan pada media agar miring dengan cara menggores. Setelah itu diinkubasi pada temperatur $36 \pm$ $1^{0} \mathrm{C}$ selama 18-24 jam. Dari stok kultur tersebut diambil satu ose steril lalu disuspensikan ke dalam tabung yang berisi $10 \mathrm{ml}$ larutan $\mathrm{NaCl}$ 0,9\% sampai didapat kekeruhan suspensi bakteri yang sama dengan kekeruhan standar McFarland, yang berarti konsentrasi suspensi bakteri adalah $10^{8} \mathrm{CFU} / \mathrm{ml}$ (Biesher, 1983; Kingscote, 1989; Carter dan Cole, 1990).

\section{Pembuatan Larutan Uji}

Ekstrak kasar yang telah dilarutkan kembali dimasukkan sebanyak $2 \mathrm{~mL}$ ke dalam kolom silika gel yang telah disiapkan. Fase gerak yang digunakan adalah etanol-air (70:30). Keran kolom dibuka penuh dan setiap tetesan sampel ditampung pada vial dengan volume $5 \mathrm{~mL}$ hingga didapatkan beberapa fraksi kemudian dianalisis secara KLT (Kartasubrata 1987, Hernani. 1999).

\section{Pengujian Efek Antibakteri Secara In vitro (Hudayanti, M., 2004)}

Metode ini menggunakan media padat dan cakram kertas (Hudayanti, M., 2004 ), kemudian hambatan pertumbuhan bakteri ditentukan dengan cara mengukur diameter zona bening disekitar cakram kertas dengan menggunakan jangka sorong. Pada tabung yang berisi $15 \mathrm{ml}$ media agar steril cair temperatur $\pm 45^{\circ} \mathrm{C}$, tambahkan suspensi bakteri sebanyak $0,1 \mathrm{~mL}$ yang telah diukur kekeruhannya. Kemudian dihomogenkan dengan bantuan vortex, lalu dituang ke dalam cawan petri steril berdiameter $9 \mathrm{~cm}$ dan biarkan memadat. Cakram kertas kemudian diteteskan larutan uji, kemudian diinkubasi pada temperatur $36 \pm 1^{0} \mathrm{C}$ dan lakukan pengamatan selama 2-24 jam. Selanjutnya diukur diameter zona bening disekitar cakram kertas dengan menggunakan jangka sorong.

\section{Identifikasi Senyawa Antibakteri Purifikasi Secara KLT}

Fraksi hasil kromatografi kolom dengan pola analisis KLT yang sama seperti pola analisis KLT saat produksi dilarutkan dalam etil asetat hingga konsentrasinya $150 \mathrm{mg} / \mathrm{mL}$. Setelah itu larutan tersebut ditotolkan pada lempeng silika gel dan dielusi dengan kloroformmetanol (9:1). Setelah elusi selesai, lempeng tersebut dilihat dibawah sinar UV dan kemudian spot yang terlihat ditandai. Spot yang telah ditandai tersebut dibandingkan dengan hasil analisis KLT sebelumnya dan spot yang sama dikerok dari lempeng KLT kemudian dilarutkan kembali dengan etanol $96 \%$ dan dipisahkan dari silika gel secara dekantasi. Visualisasi dilakukan dengan melihat di bawah sinar UV atau dengan penambahan larutan penampak spot.

\section{Profil Kimiawi Menggunakan KCKT}

Fraksi hasil KLT terbaik yang memiliki aktivitas inhibisi terhadap bakteri, selanjutnya difraksinasi menggunakan KCKT Shimadzu CLASS-VP, menggunakan kolom C18 (3,9 x 150 mm, 4 $\mu \mathrm{m})$ dengan fase alir berupa metanol-air berbagai perbandingan dan laju alir 1 $\mathrm{ml} /$ menit. Detektor UV pada panjang gelombang 280-500 nm dan volume injeksi 20 $\mu$ l. Setiap puncak yang terpisah, kemudian dibandingkan dengan standar.

\section{HASIL DAN PEMBAHASAN \\ Identifikasi Tumbuhan}

Hasil identifikasi rimpang kunyit yang dilakukan oleh Herbarium Bogoriense, Bidang Botani Pusat Penelitian Biologi LIPI Cibinong Bogor adalah jenis 
Curcuma longa L., dari suku Zingiberaceae.

\section{Karakterisasi dan Identifikasi \\ Komponen Rimpang Kunyit \\ Ekstrak Kasar Rimpang Kunyit}

Evaporasi menggunakan Rotary Evaporator pada temperature $50^{\circ} \mathrm{C}$ menghasilkan ekstrak kering rimpang kunyit dapat dilihat pada tabel 1

Tabel 1.Ekstrak Kering Hasil Maserasi

\begin{tabular}{|c|c|c|}
\hline No & Pelarut & $\begin{array}{c}\text { Ekstak } \\
\text { Kering } \\
(\%)\end{array}$ \\
\hline 1. & n - Heksan & 1.175 \\
\hline 2. & Etil asetat & 0.51 \\
\hline 3. & Etanol & 3.91 \\
\hline
\end{tabular}

Bobot ekstrak kering dari ketiga pelarut menunjukkan hasil yang berbeda, dimana hasil ekstrak kering dengan pelarut etanol diperoleh bobot yang lebih besar dibandingkan pelarut etil asetat maupun nheksan. Data tersebut menunjukkan dugaan bahwa kurkumin terkandung dalam ekstrak rimpang kunyit.

Kurkuminoid merupakan senyawa yang bersifat polar, kepolarannya disebabkan oleh gugus $-\mathrm{OH}$ yang terdapat pada struktur kurkuminoid. Kurkuminoid larut dalam pelarut-pelarut mempunyai kepolaran yang hampir sama. Etanol memliki kepolaran mirip dengan kurkuminoid sehingga cocok digunakan untuk mengekstrak kurkuminoid. Hasil penelitian Sidik (1985) sebelumnya memperlihatkan kadar kurkuminoid terbesar yang terekstrak terdapat dalam pelarut aseton dan etanol. Suwiah (1991), Pigmen kurkumin larut dalam pelarut polar seperti etanol, karena tingkat kepolaran kurkumin.

Tabel 2 .Zona Hambat Pada Bakteri Pseudomonas aeruginosa

\begin{tabular}{|c|l|c|c|c|c|c|}
\hline \multirow{2}{*}{ No. } & \multirow{2}{*}{ Pelarut } & \multicolumn{5}{|c|}{ Zona Hambat (mm)/ Lama Inkubasi } \\
\cline { 3 - 7 } & 2 jam & 4 jam & 6 jam & 8 jam & $\begin{array}{c}24 \\
\text { jam }\end{array}$ \\
\hline 1 & n-Heksan & 6 & 6 & 0 & 0 & 0 \\
\hline 2 & $\begin{array}{l}\text { Etil } \\
\text { Asetat }\end{array}$ & 6 & 6 & 0 & 0 & 0 \\
\hline 3 & Etanol & 6 & 6 & 7 & 6 & 0 \\
\hline
\end{tabular}

\section{Uji Antibakteri}

\section{Uji Antibakteri Masing-masing Pelarut}

Hasil ekstrak kering masing-masing pelarut kemudian dilarutkan kembali menjadi $3 \mathrm{~mL}$ larutan. Larutan dibagi menjadi 2 bagian, yaitu $1 \mathrm{~mL}$ untuk uji antibakteri dan $2 \mathrm{~mL}$ untuk kromatografi kolom. Disiapkan media Nutrient Agar sebanyak $\pm 15 \mathrm{~mL}$ pada 4 buah cawan petri yang masing-masing telah ditambahkan dengan bakteri Pseudomonas aeruginosa, Bacillus subtilis, Escherichia coli, dan Salmonella typhosa. Setelah media memadat, cakram kertas diletakkan di atas media agar dengan menggunakan pinset steril. Kemudian diteteskan larutan ekstrak $\pm 15 \mu \mathrm{L}$ di atas paper disc lalu diinkubasi pada temperatur $36^{\circ} \mathrm{C} \pm 1{ }^{\circ} \mathrm{C}$ dan dilakukan pengamatan setelah 2 jam, 4 jam, 6 jam, 8 jam, dan 24 jam

Hasil pengamatan uji anti bakteri tertera pada tabel di bawah ini.

Tabel 3.Zona Hambat Pada Bakteri Bacillus subtilis

\begin{tabular}{|c|l|c|c|c|c|c|}
\hline \multirow{2}{*}{$\begin{array}{l}\text { N } \\
\text { o. }\end{array}$} & \multirow{2}{*}{ Pelarut } & \multicolumn{5}{|c|}{ Zona Hambat (mm)/ Lama Inkubasi } \\
\cline { 3 - 7 } & 2 jam & 4 jam & 6 jam & 8 jam & $\begin{array}{c}24 \\
\text { jam }\end{array}$ \\
\hline 1 & n-Heksan & 6 & 6 & 0 & 0 & 0 \\
\hline 2 & Etil asetat & 6 & 0 & 0 & 0 & 0 \\
\hline 3 & Etanol & 6 & 0 & 0 & 0 & 0 \\
\hline
\end{tabular}


Pada bakteri Pseudomonas aeruginosa ekstrak n-heksan memiliki zona hambat sebesar $6 \mathrm{~mm}$ pada pengamatan waktu inkubasi 2 jam dan 4 jam. Sedangkan untuk ekstrak etanol dan ekstrak etil asetat hanya memiliki zona hambat pada pengamatan waktu inkubasi 2 jam sebesar $6 \mathrm{~mm}$.

Ekstrak n-heksan dan ekstrak etil asetat memiliki zona hambat sebesar $6 \mathrm{~mm}$ pada pengamatan waktu inkubasi 2 jam dan 4 jam pada bakteri Bacillus subtilis. Sedangkan pada ekstrak etanol didapatkan zona hambat yang baik hingga waktu pengamatan inkubasi 8 jam.

Tabel 4. Zona Hambat Pada Bakteri Escherichia coli

\begin{tabular}{|c|l|c|c|c|c|c|}
\hline \multirow{2}{*}{ No } & \multirow{2}{*}{ Fraksi } & \multicolumn{5}{|c|}{ Zona Hambat (mm)/ Lama Inkubasi } \\
\cline { 2 - 7 } & 2 jam & 4 jam & 6 jam & 8 jam & $\begin{array}{c}24 \\
\text { jam }\end{array}$ \\
\hline 1 & $\begin{array}{l}\text { Kloramfeni } \\
\text { kol }\end{array}$ & 6 & 6 & 0 & 0 & 0 \\
\hline 2 & Fraksi 7 & 6 & 6 & 0 & 0 & 0 \\
\hline 3 & Fraksi 6 & 6 & 6 & 0 & 0 & 0 \\
\hline 4 & Fraksi 5 & 6 & 6 & 0 & 0 & 0 \\
\hline 5 & Fraksi 4 & 6 & 6 & 6 & 0 & 0 \\
\hline 6 & Fraksi 3 & 6 & 7 & 7 & 0 & 0 \\
\hline 7 & Fraksi 2 & 6 & 7 & 6 & 0 & 0 \\
\hline 8 & Fraksi 1 & 6 & 6 & 0 & 0 & 0 \\
\hline
\end{tabular}

Tabel 5. Zona Hambat Pada Bakteri Salmonella typhosa

\begin{tabular}{|c|l|c|c|c|c|c|}
\hline \multirow{2}{*}{ No. } & \multirow{2}{*}{ Pelarut } & \multicolumn{5}{|c|}{ Zona Hambat (mm)/ Lama Inkubasi } \\
\cline { 3 - 7 } & & 2 jam & 4 jam & 6 jam & 8 jam & $\begin{array}{c}24 \\
\text { jam }\end{array}$ \\
\hline 1 & n-Heksan & 6 & 6 & 0 & 0 & 0 \\
\hline 2 & Etil asetat & 6 & 6 & 6 & 0 & 0 \\
\hline 3 & Etanol & 6 & 6 & 10 & 13 & 0 \\
\hline
\end{tabular}

Ekstrak etanol memberikan zona hambat yangbaik terhadap bakteri Escherichia coli. Hasil pengamatan didapatkan diameter zona hambat yang semakin besar pada tiap-tiap pengamatan waktu inkubasi yaitu hingga inkubasi 8 jam.

Tabel 6. Zona Hambat Pada Bakteri Pseudomonas aeruginosa

\begin{tabular}{|c|l|c|c|c|c|c|}
\hline \multirow{2}{*}{$\begin{array}{l}\mathrm{N} \\
\text { o. }\end{array}$} & Pelarut & \multicolumn{5}{|c|}{ Zona Hambat (mm)/ Lama Inkubasi } \\
\cline { 3 - 7 } & 2 jam & 4 jam & 6 jam & 8 jam & $\begin{array}{c}24 \\
\text { jam }\end{array}$ \\
\hline 1 & n-Heksan & 6 & 6 & 0 & 0 & 0 \\
\hline 2 & $\begin{array}{l}\text { Etil } \\
\text { Asetat }\end{array}$ & 6 & 7 & 0 & 0 & 0 \\
\hline 3 & Etanol & 6 & 6 & 7 & 12 & 0 \\
\hline
\end{tabular}

Ekstrak etanol juga memberikan zona hambat yang baik terhadap bakteri Salmonella thyposa. Hasil pengamatan didapatkan diameter zona hambat yang semakin besar pada tiap-tiap pengamatan waktu inkubasi yaitu hingga inkubasi 8 jam.

\section{Uji Antibakteri Masing-masing Fraksi}

Pada pengujian antibakteri awal didapatkan zona hambat terbaik pada ekstrak dengan pelarut etanol. $2 \mathrm{~mL}$ ekstrak etanol ditambahkan silika kemudian dimasukkan ke dalam kromatografi kolom dengan fase diam silika gel $\mathrm{F}_{254}$ dan fase gerak etanol-air (70:30) sehingga didapatkan beberapa fraksi. Fraksi-fraksi tersebut ditotolkan pada paper disc yang telah diletakkan di atas media Nutrient Agar kemudian diinkubasi dan diamati pada waktu inkubasi 2 jam, 4 jam, 6 jam, 8 jam, dan 24 jam.

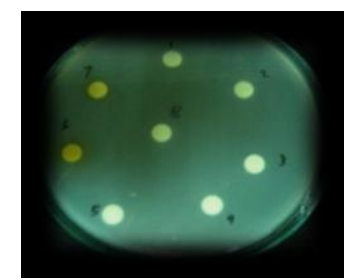

Gambar 1. Uji Aktivitas Antibakteri Pada Pseudomonas aeruginosa 
* 1: kloramfenikol; 2: fraksi 7; 3: fraksi 6; 4: fraksi 5; 5: fraksi 4; 6: fraksi 3; 7: fraksi 2; 8: fraksi 1

Pada bakteri Pseudomonas aeruginosa zona hambat pada pengamatan waktu inkubasi 2 jam dan 4 jam menunjukkan diameter zona hambat yang baik. Pada pengamatan waktu inkubasi 6 jam hingga 24 jam, ektrak yang diuji tidak memberikan daya hambat terhadap pertumbuhan bakteri Pseudomonas aeruginosa, kecuali fraksi 2, 3, dan 4 yang masih menunjukkan zona hambat pada pengamatan waktu inkubasi 6 jam.

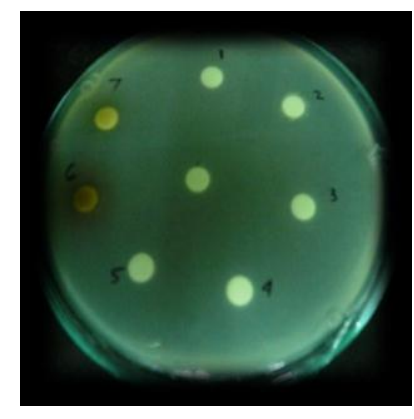

Gambar 2.Uji Aktivitas Antibakteri Pada Bacillus subtilis

* 1: kloramfenikol; 2: fraksi 7; 3: fraksi 6; 4: fraksi 5; 5: fraksi 4; 6: fraksi 3; 7: fraksi 2; 8 : fraksi 1

Tabel 7. Zona Hambat Pada Bakteri

Bacillus subtilis

\begin{tabular}{|c|l|c|c|c|c|c|}
\hline \multirow{2}{*}{$\begin{array}{c}\text { N } \\
\text { o. }\end{array}$} & \multicolumn{2}{|c|}{ Fraksi } & \multicolumn{4}{|c|}{ Zona Hambat (mm)/ Lama Inkubasi } \\
\cline { 2 - 7 } & $\begin{array}{c}2 \\
\text { jam }\end{array}$ & $\begin{array}{c}4 \\
\text { jam }\end{array}$ & $\begin{array}{c}6 \\
\text { jam }\end{array}$ & $\begin{array}{c}8 \\
\text { jam }\end{array}$ & $\begin{array}{c}24 \\
\text { jam }\end{array}$ \\
\hline 1 & $\begin{array}{l}\text { Kloramfeniko } \\
1\end{array}$ & 6 & 6 & 0 & 0 & 0 \\
\hline 2 & Fraksi 7 & 6 & 6 & 0 & 0 & 0 \\
\hline 3 & Fraksi 6 & 6 & 6 & 0 & 0 & 0 \\
\hline 4 & Fraksi 5 & 6 & 6 & 6 & 0 & 0 \\
\hline 5 & Fraksi 4 & 6 & 6 & 6 & 0 & 0 \\
\hline 6 & Fraksi 3 & 6 & 7 & 8 & 8 & 0 \\
\hline 7 & Fraksi 2 & 6 & 7 & 6 & 6 & 0 \\
\hline 8 & Fraksi 1 & 6 & 6 & 0 & 0 & 0 \\
\hline
\end{tabular}

Pada bakteri Bacillus subtilis, ekstrak etanol menunjukkan zona hambat yang baik hingga pengamatan waktu inkubasi 8 jam yaitu pada fraksi 2 dan fraksi 3. Sedangkan pada fraksi 4 dan fraksi 5 hanya menunjukkan zona hambat pada pengamatan waktu inkubasi 2 hingga 6 jam.

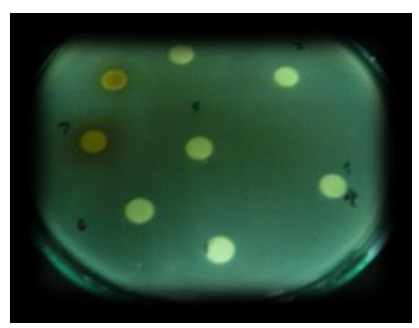

Gambar 3. Uji Aktivitas Antibakteri Pada Escherichia coli

* 1: kloramfenikol; 2: fraksi 7; 3: fraksi 6;

4: fraksi 5; 5: fraksi 4; 6: fraksi 3; 7: fraksi 2; 8: fraksi 1

Tabel 8. Zona Hambat Pada Bakteri Escherichia coli

\begin{tabular}{|c|l|c|c|c|c|c|}
\hline \multirow{2}{*}{ No } & \multirow{2}{*}{ Fraksi } & \multicolumn{4}{|c|}{ Zona Hambat (mm)/ Lama Inkubasi } \\
\cline { 3 - 7 } & & 2 & 4 jam & 6 jam & 8 jam & $\begin{array}{c}24 \\
\text { jam }\end{array}$ \\
\hline 1 & Kloramfenikol & 6 & 6 & 0 & 0 & 0 \\
\hline 2 & Fraksi 7 & 6 & 6 & 0 & 0 & 0 \\
\hline 3 & Fraksi 6 & 6 & 6 & 0 & 0 & 0 \\
\hline 4 & Fraksi 5 & 6 & 7 & 7 & 7 & 0 \\
\hline 5 & Fraksi 4 & 6 & 7 & 7 & 7 & 0 \\
\hline 6 & Fraksi 3 & 6 & 8 & 13 & 13 & 7 \\
\hline 7 & Fraksi 2 & 6 & 7 & 9 & 9 & 6 \\
\hline 8 & Fraksi 1 & 6 & 6 & 6 & 0 & 0 \\
\hline
\end{tabular}

Pengamatan pada bakteri Escherichia coli menunjukkan diameter zona hambat yang baik terutama pada fraksi 2 dan fraksi 3, karena zona hambat tetap terbentuk hingga pengamatan waktu inkubasi 24 jam. Zona hambat juga terbentuk dengan baik pada fraksi 4 dan fraksi 5 karena zona terbentuk hingga pengamatan waktu inkubasi 8 jam. 


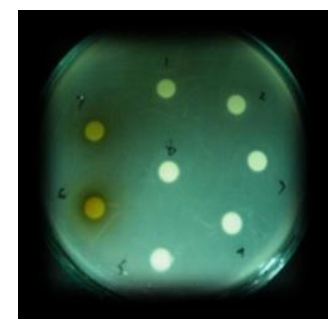

Gambar 4. Uji Aktivitas Antibakteri Pada Salmonella typhosa

* 1: kloramfenikol; 2: fraksi 7; 3: fraksi 6; 4: fraksi 5; 5: fraksi 4; 6: fraksi 3; 7: fraksi 2; 8: fraksi 1

Tabel 9. Zona Hambat Pada Bakteri Salmonella typhosa

\begin{tabular}{|c|l|c|c|c|c|c|}
\hline \multirow{2}{*}{$\begin{array}{c}\text { No } \\
\cdot\end{array}$} & \multirow{2}{*}{ Fraksi } & \multicolumn{5}{|c|}{ Zona Hambat (mm)/ Lama Inkubasi } \\
\cline { 3 - 7 } & & $\mathbf{2}$ & $\mathbf{4}$ & $\mathbf{6}$ & $\mathbf{8}$ & $\mathbf{2 4}$ \\
\hline 1 & Kloramfenikol & 6 & 6 & 0 & 0 & 0 \\
\hline 2 & Fraksi 7 & 6 & 6 & 0 & 0 & 0 \\
\hline 3 & Fraksi 6 & 6 & 6 & 0 & 0 & 0 \\
\hline 4 & Fraksi 5 & 6 & 7 & 7 & 7 & 0 \\
\hline 5 & Fraksi 4 & 6 & 7 & 7 & 7 & 0 \\
\hline 6 & Fraksi 3 & 6 & 8 & 12 & 13 & 8 \\
\hline 7 & Fraksi 2 & 6 & 7 & 9 & 9 & 6 \\
\hline 8 & Fraksi 1 & 6 & 6 & 7 & 6 & 0 \\
\hline
\end{tabular}

Pengamatan pada bakteri Salmonellatyphi memiliki kesamaan dengan bakteri Escherichia coli dimana zona hambat tetap terbentuk hingga pengamatan waktu inkubasi 24 jam pada fraksi 2 dan fraksi 3. Zona hambat ekstrak etanol pada bakteri Pseudomonas aeruginosa, Bacillus subtilis, Escherichia coli, dan Salmonella typhosa baik pada fraksi 2 dan fraksi 3, ditunjukkan dengan diameter zona hambat yang terbentuk dan lama waktu inkubasi. Hal ini memperkuat dugaan bahwa dalam fraksi 2 dan fraksi 3 terkandung kurkumin.

\section{Uji Antibakteri Preparatif}

Uji antibakteri pada fraksi-fraksi hasil kromatografi kolom menunjukkan zona hambat yang paling baik pada fraksi 2 dan fraksi 3. Kedua fraksi tersebut dianalisis dengan kromatografi lapis tipis. Penampakan noda pada plat KLT dilihat di bawah sinar UV dengan $\lambda 256 \mathrm{~nm}$, kemudian diberi tanda. Noda yang telah diberi tanda dikerok dan dilarutkan kembali dengan etanol, kemudian larutan dipisahkan dari endapan lalu diuji aktivitas antibakteri terhadap bakteri Salmonella typhosa dan Escherichia coli.

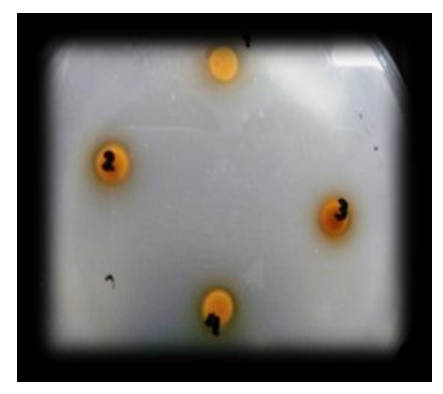

Gambar 5. Uji Aktivitas Antibakteri Pada Salmonella typhosa

* 1: kurkumin standar; 2: preparatif $1 ; 3$ : preparatif $2 ; 4$ : preparatif 3

Tabel 10. Zona Hambat Pada Bakteri Salmonella typhosa

\begin{tabular}{|c|l|c|c|c|c|c|}
\hline \multirow{2}{*}{$\begin{array}{c}\text { N } \\
\text { o. }\end{array}$} & Fraksi & \multicolumn{5}{|c|}{ Zona Hambat (mm)/ Lama Inkubasi } \\
\cline { 3 - 7 } & 2 jam & 4 jam & 6 jam & 8 jam & $\begin{array}{c}24 \\
\text { jam }\end{array}$ \\
\hline 1 & Kontrol & 6 & 8 & 10 & 10 & 8 \\
\hline 2 & $\begin{array}{l}\text { Preparati } \\
\text { f 1 }\end{array}$ & 6 & 9 & 12 & 12 & 8 \\
\hline 3 & $\begin{array}{l}\text { Preparati } \\
\text { f 2 }\end{array}$ & 6 & 8 & 13 & 13 & 8 \\
\hline 4 & $\begin{array}{l}\text { Preparati } \\
\text { f 3 }\end{array}$ & 6 & 7 & 6 & 6 & 0 \\
\hline
\end{tabular}

Hasil KLT didapatkan 3 senyawa yang memiliki kesamaan dengan kurkumin standar. Senyawa yang telah dipisahkan dan diuji antibakteri, memiliki daya hambat yang baik terhadap bakteri Salmonella 
typhosa. Pengamatan waktu inkubasi pada uji antibakteri didapatkan zona hambat yang baik pada preparatif 1 dan preparatif 2 dengan memberikan daya hambat yang baik hingga pengamatan waktu inkubasi 24 jam.

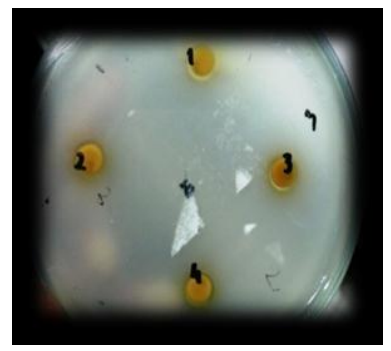

Gambar 6. Uji Aktivitas Antibakteri Pada Escherichia coli

* 1: kurkumin standar; 2: preparatif 1; 3 : preparatif $2 ; 4$ : preparatif 3

Tabel 11. Zona Hambat Pada Bakteri Escherichia coli

\begin{tabular}{|c|l|c|c|c|c|c|}
\hline \multirow{2}{*}{$\begin{array}{c}\text { N } \\
\text { o. }\end{array}$} & \multirow{2}{*}{ Fraksi } & \multicolumn{4}{|c|}{ Zona Hambat (mm)/ Lama Inkubasi (jam) } \\
\cline { 3 - 7 } & 2 & 4 & 6 & 8 & 24 \\
\hline 1 & Kontrol & 6 & 8 & 10 & 10 & 7 \\
\hline 2 & $\begin{array}{l}\text { Preparati } \\
\text { f 1 }\end{array}$ & 6 & 9 & 10 & 12 & 8 \\
\hline 3 & $\begin{array}{l}\text { Preparati } \\
\text { f 2 }\end{array}$ & 6 & 8 & 9 & 12 & 7 \\
\hline 4 & $\begin{array}{l}\text { Preparati } \\
\text { f 3 }\end{array}$ & 6 & 7 & 6 & 6 & 0 \\
\hline
\end{tabular}

Uji antibakteri hasil preparatif dari KLT terhadap bakteri Escherichia coli didapatkan hasil yang mendekati kurkumin standar. Hasil uji antibakteri menunjukkan zona hambat yang baik pada pengamatan waktu inkubsai hingga 24 jam. Zona hambat yang baik terlihat pada preparatif 1 dan preparatif 2 .

\section{Purifikasi dengan KLT}

Analisis KLT menggunakan campuran kloroform-metanol (9:1). Fase gerak tersebut dipilih karena kemampuan metanol untuk meningkatkan polaritas kloroform sehingga terbentuk suatu sistem eluen yang dapat memisahkan komponen dalam ekstrak berdasarkan nilai retardation factor (Rf) dalam ekstrak dengan baik (Khopkar, 1990).

Nilai Rf suatu komponen ditentukan juga oleh fase diam. Fase diam yang digunakan pada analisis KLT ini adalah silika gel $F_{254}$. Silika gel adalah senyawa yang polar dan angka 254 adalah panjang gelombang sinar UV yang dapat diserapnya (Khopkar, 1990).

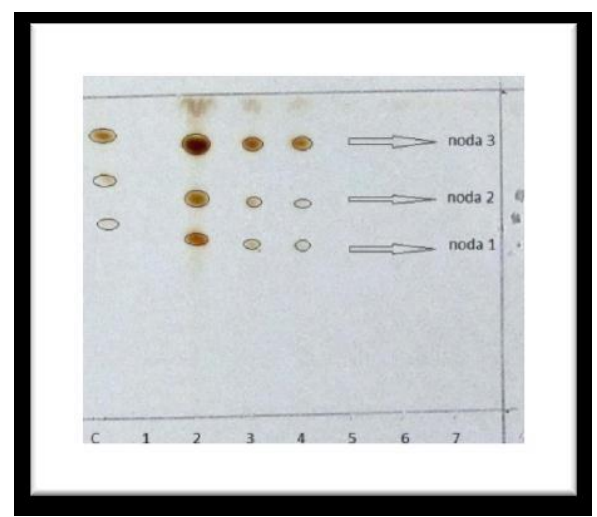

Gambar 7. Fraksi Hasil Pemisahan dengan Kromatografi Kolom

Ekstrak etanol kunyit yang pada awal diuji telah menunjukkan efektivitasnya terhadap pertumbuhan bakteri Pseudomonas aeruginosa, Bacillus subtilis, Escherichia coli, dan Salmonella typhosa kemudian dimasukkan ke dalam kromatogafi kolom sehingga terbentuk beberapa fraksi. Hasil fraksinasi tersebut dianalisis dengan kromatografi lapis tipis sehingga membentuk beberapa noda warna pada setiap fraksinya. Pada kromatografi kolom didapatkan 7 fraksi hasil pemisahan dengan fase gerak etanol-air (70:30) dan pada kromatografi lapis tipis, fraksi yang menunjukkan penampakan noda yang mendekati kurkumin standar terlihat pada Gambar 6.

Komponen kurkuminoid diketahui mempunyai berbagai aktivitas hayati dalam 
spektrum yang luas.Dibandingkan dengan penelitian sebelumnya yang menggunakan rimpang temulawak, fraksi kurkuminoid dalam rimpang temulawak terdiri atas dua komponen, yaitu kurkumin dan desmetoksikurkumin (Basalmah R.S., 2006). Pada penelitian ini kurkuminoid pada rimpang kunyit diduga selain mengandung kurkumin dan desmotoksikurkumin juga mengandung komponen lain dari kurkuminoid yaitu bisdesmetoksikurkumin.

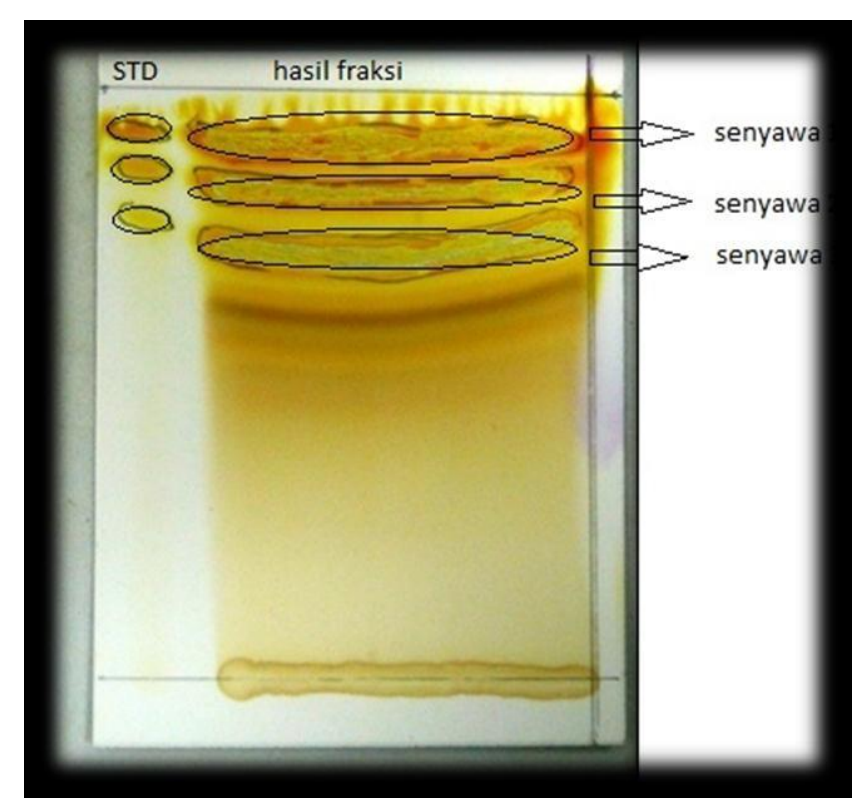

Gambar 8. Pola KLT Preparatif

Pada fraksinasi pertama didapatkan 7 fraksi hasil pemisahan dengan kromatografi kolom yang kemudian diujikan daya hambatnya terhadap bakteri Pseudomonas aeruginosa, Bacillus subtilis, Escherichia coli, dan Salmonella typhosa. Hasil uji daya hambat dan kromatografi kolom memiliki kesamaan yaitu fraksi yang memiliki daya hambat dan profil penampakan noda yang mendekati kurkumin standar adalah fraksi 2 dan fraksi 3.

Dari kedua fraksi tersebut dianalisis kembali dengan kromatografi lapis tipis sehingga diperoleh hasil preparatif seperti terlihat pada Gambar 7. Hasil preparatif kemudian dikerok dan dilarutkan kembali dengan etanol untuk selanjutnya dianalisis dengan KCKTserta uji daya hambatnya terhadap bakteri Escherichia coli dan Salmonella typhosa.

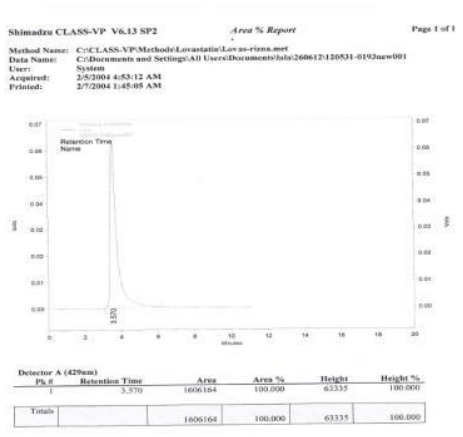

Pada Tabel 12 terlihat bahwa sampel dan kurkumin standar memiliki waktu retensi yang hampir sama. Waktu retensi yang sama dapat menunjukkan senyawa yang sama. Hasil KCKT (Gambar 9) diperoleh waktu retensi puncak kromatogram yang sama dengan kurkumin standar (Gambar 8).
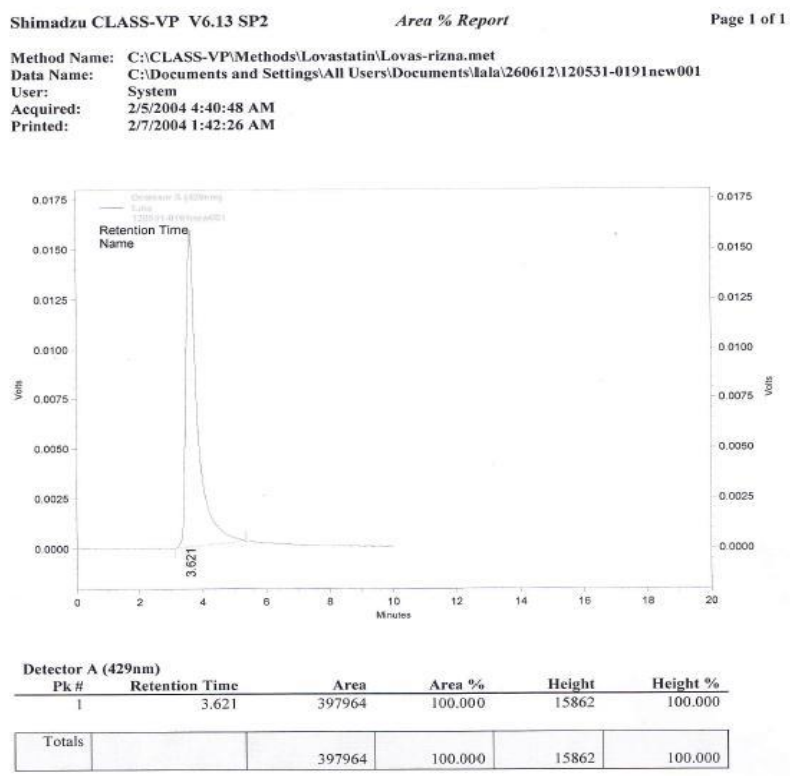
Waktu retensi menunjukkan waktu yang diperlukan oleh suatu senyawa untuk bergerak melalui kolom menuju detektor. Waktu retensi diukur berdasarkan waktu dimana sampel diinjeksikan sampai sampel menunjukkan ketinggian puncak yang maksimum dari senyawa tersebut.

\section{DAFTAR PUSTAKA}

Batubara I, Yusnira, Darusman LK. 2004. Penentuan Kadar Kurkuminoid pada Temulawak Menggunakan Metode Spektroskopi dan Kromatografi Cairan Kinerja Tinggi. Di dalam: Seminar Nasional Hasil Penelitian MIPA 2004; Semarang: FMIPA Universitas Diponegoro. Hlm 5760 .

Biesher. 1983. Microbiology in Practice. Individualized Introduction for The Allied Heath Science. 3rd ed. Harper and Row Publisher. New York

Carter, G.R. and J.R. Cole, Jr. 1990. Diagnostic Procedures in Veterinary Bacteriology and Micology. 5th ed. Academic Press. Inc. San Diego California. 108-123

Guenther, E. 1987. The Essential Oils. Terjemahan. Ketaren, S. 1987. Minyak Atsiri. Jilid I. Pharmacology Reviews. Vol 1 (1). 119-128.

Hernani. 1999. Teknik identifikasi bahan aktif pada tumbuhan obat. Makalah pada Seminar Pendalaman Materi di Balai Penelitian Tanaman Rempah dan Obat, Bogor

Hudayanti, M., 2004, "Aktivitas Antibakteri Rimpang Temulawak (Curcuma xanthorrihza Roxb.)", Skripsi Jurusan Kimia, Institut Pertanian Bogor, Bogor. Hal: 6, 8-9, 21
Jain, S., Shapiro.,Swanick.Mills PJ., 2007. PHCOG : Plant Review Tre in Curcuma longa Linn. Jakarta: Universitas Indonesia. Hlm. 287289.

Kartasubrata, Y. 1987. Dasar-dasar kromatografi. Makalah pada Kursus Metode Analisis Instrumental. Pusat Penelitian dan Pengembangan Kimia Terapan, Lembaga Ilmu Pengetahuan Indonesia, Bandung

Khopkar SM. 1990. Konsep Dasar Kimia Analitik. Penerjemah: Saptorahardjo A. Jakarta: UI Press.

Kingscote, B. $1989 . \quad$ Veterinary Microbiology Introduction to Bacteria and Virology. 7th ed. The Iowa State University Press. Ames. Iowa. USA.

Rahmat BS 2006 Optimalisasi Kondisi Ekstraksi Kurkumoid Temulawak : Waktu , Suhu Dan Nisbah Skripsi Jurusan Kimia, Institut Pertanian Bogor, Bogor.

Rukmana, Ir. Rahmat. 1994. Kunyit. Yogyakarta: Kanisius. Hal. 1-25. Singh R dan Rai B.2000. Anti Fungal Potential of some Higher Plants Against Fusarimudum causing Wilt Disease of Cajanus Cajan Microbios. 02:165-173

Suwih A. 1991. Pengaruh perlakuan bahan dan jenis pelarut yang digunakan pada pembuatan temulawak instant terhadap rendemen dan mutunya [skripsi]. Bogor: Fakultas Teknologi Pertanian, Institut Pertanian Bogor.

Tjay, T.H dan Rahardja,K. 2002. Obat obat Penting : Khasiat, Penggunaan dan Efek Efek Sampingnya. Edisi VI. Jakarta : Penerbit PT. Alex Media Komputindo. Halaman 540-541 